\title{
The Art of Skirmishing
}

\section{Lieut.-Colonel R. Holden}

To cite this article: Lieut.-Colonel R. Holden (1900) The Art of Skirmishing, Royal United Services Institution. Journal, 44:267, 552-559, DOI: 10.1080/03071840009420007

To link to this article: http://dx.doi.org/10.1080/03071840009420007

$$
\text { 曲 Published online: } 11 \text { Sep } 2009 .
$$

Submit your article to this journal

LII Article views: 5

Q View related articles $\sqsubset$ 


\title{
THE ART OF SKIRMISHING.
}

\author{
By. Lieut.-Colonel R. HOLDEN, Secrelary, Royal United Selvice \\ Institution.
}

THE art of skirmishing is as old as war itself. It was employed by the "Psilites" of the Greek Phalanx, by the archers and slingers of the carly" Egyptians and Jews, by the "Velites" of the Roman Legion, and by the light infantry of the Anglo-Saxons. The duty of skirmishers was then, as it is now, to reconnoitre the country in their front, feel for the enemy, hide the movements of the main body, prepare the way for troops advancing, and cover a retreat.

In the middle of the eighteenth century, excepting by Frederick, the general method of fighting in use in all countries was for the advance to be covered by troops, in extended order, halting, firing, loading, and running forward, whilst the closed battalion followed in rear without checking. If the attack failed, then, whilst retreating, named files had to halt, front, fire, and regain their places in the ranks. The men so employed were of superior intelligence, bodily condition, and skill with the musket.

England employed sharpshooters and companics of light infantry, in a half-hearted manner, during the conquest of Canada, but not until scrious reverses had taught her the wisdom of so doing.' She entered on the campaign with a haughty disregard of the necessity for scouting, reconnoitring, secking cover, or of advanced and rear guards. But the lessons learned in Canada were soon forgotten, and the Army entered upon the War of American Independence imperfectly instructed, ${ }^{2}$ and ill-prepared to meet the irregular tactics of the colonists. Marksmen from their youth, and placed in houses, behind walls, and amongst trees and other covert, the Americans inflicted very serious damage on our troops.

During the long war with France, which commenced in 1793, the subject of skirmishing was taken in hand with becoming serious-

${ }^{1}$ Companies of light infantry were first formed in the British Army on the 14th May, 1758, in America, but were discontinued at the Peace in 1763. Regiments of light infantry were formed at the same time, the first of which was the old 80th, formed in 1758 , and disbanded in 1703 ; the $85 \mathrm{th}$, formed in 1759 , and disbanded in 1763; the 90th, formed in 1759 , and disbanded in 1763. Companies of light infantry were introduced into the Army as a permanent institution in 1770 . 71. - R. H.

${ }^{2}$ In 1774 seven light companies were formed into a battalion at Salisbury, to practise a scries of manouvres invented by General Sir William Howc, who was appointed to instruct them. 
ness, but the mode of fighting differed very much from that imployed in Canada and America. The present 2nd Bn. of the Scottish Rifles was raised in 1794, and trained as a light infantry corps, and for years was the only corps of the kind in the British Line. Next followed the addition of a rifle battalion to the 60th Foot in 1797 , the formation of the present Rifle Brigade as an experimental corps in 1800 , and the training of the 52nd and 43rd as light infantry by Sir John Noore at Shorncliffe in 1804-5. ${ }^{1}$ Skirmishing had a recognised place in the Drill-Book before the end of the century, and in Dundas's "Eighteen Manœuvres" instructions are given for the light companies covering the advance and retirement in line, etc. According to the official manuals of the period, vigilance, intelligence, good marksmanship, activity, and rapidity of movement were the chief characteristics of good light infantry; they were expected to take advantage of every circumstance of ground without exposing themselves, and were in consequence exercised over every variety of ground. They were taught to shelter themselves in hollows, behind walls, hedges, trees, stones, and indeed any obstacle. They would gain upon an enemy along hedges, through crops, gardens, and ditches without being observed, and make rushes from one covered situation to another; they used their own discretion as to closing or extending in moderation according to the nature of the ground, but two men at least remained together for mutual support. While carefully protecting their own, they worked upon the flanks of the enemy whilst secking to occupy his attention in front, and were taught to treat cavalry and artillery with contempt. It was a recognised principle that skirmishers on all occasions had portion of their force as supports, and portion in reserve. In covering a retreat, shirmishers were invaluable They retired as slowly as possible, the officers looking well to their supports, and taking every advantage of the ground and the objects the locality presented for cover. The men worked in two ranks, front and rear rank firing alternately; the distance between the files varied, as occasion required, from two fect, and extensions were made from the right, left, or centre. The pace was quick for the period-120 to 150 paces to the minute, but doubling was rarely permitted. When once the men were extended, the movements were performed by bugle."

The system varied somewhat in different regiments, and was in detail improved upon by the experience gained during the war with France. In 1798 Baron de Rottenburg, who commanded the newlyraised Jäger battalion of the 60th, wrote a book on the drill of riflemen and outpost duties, and for light infantry and their conduct in the field,

'The 52 2nd were converted into light infantry in January, 1803, and the $43 \mathrm{rd}$ in July, 1803.

2 When light companies were first formed in infantry regiments, they, in common with the rest of the Army, used drums, and it was not until about 1790 that they adopted the "bugle-horn," the first mention of which occurs in Rules and Regulations for the Formations, Fisld Exercise, and Movements of His Mlajesty's Forces, June, 1792. The bugle in its original form was curved like the badge of rifles and light infantry. 
which the Duke of York ordered to be officially published. Colonel Coote Manningham and Iicut.-Coloncl William Stewart, of the 95th (Rifle) Regiment, and Lieut.-Colonel Kenneth. Mackenzie, of the .52nd Light Infantry, were also great instructors in the art of skirmishing. In the spring of 1803 Colonel Coote Manningham delivered an interesting series of lectures at Shorncliffe to the officers of the regiment. It is impossible to reproduce them here in full, but some extracts will show how fully that officer understood the duties of light troops. "They are, as it were, a light or beacon for the general, which should constantly inform him of the situation, the movements, and nature of the enemy's designs; it is upon the exactness and intelligence of what they report that he is cnabled to regulate the time and manner of executing his own enterprises. The officer who is deprived of this support, whether it be for want of sufficient numbers or their want of expertness in this particular branch of the military art, being soon circumvented, ignorant of what his enemy is preparing to execute, and arriving constantly. too late to prevent some mischief, will experience daily losses, checks without end, and such disheartening circumstances as may lead eventually to a general defeat. The safety of an army, the justness of those measures which have'so direct an influence upon success, depend frequently on the vigilance, the expertness, and the superiority of the light troops compared with those of the enemy. The chief merit of this part of the military profession is not founded upon the old and practised stratagems of a partisan only, as some may think; it is requisite to add to them an exact method and reflections that are intimately connected with the grand operations of war. Every officer of light troops should know how to occupy a post, how to keep it, to support it, or to retire from it when requisite. $\mathrm{He}$ should be well acquainted with the means and precautions necessary to secure himself upon all marches, how to penetrate the enemy's chain of sentries, to reconnoitre his position, his force, and his movements, the circumstances which favour an attack on those places he may occupy, as well as such as are unfavourable to himself when attacking." There are invaluable instructions on scouting, patrolling, and reconnoitring, and advanced guards by day and night, which might be studied with advantage at the present day. Sir John Moore instructed the 43rd, 52nd, and 95th Rifles at Shorncliffe in 1804-5, and finally Major-General Craufurd, with his celebrated light division, so improved upon and perfected the art of skirmishing and the movements of light infantry that no army was better served in this respect during the Peninsular War than the British. Skirmishing was a highly cultivated art, practised in most contingencies, in various kinds of warfare, by small as well as by large bodies of troops, by outposts and pickets when attacked, and by advanced and by rear guards and patrols; they were to the army what detective police are to the public.

The Duke of Wellington made good use of skirmishers. He moved in formations most suited to the ground the troops were required to traverse; but, under cover of skirmishers, deployed before making his 
attack. With the weapons of his day the fire of the individual soldier was not a factor of importance in the problem to be worked out; the effect of men fighting in a formed body, shoulder to shoulder, was the chief consideration, and the tendency of all drill and tactical instruction was to make men rely upon their united strength as a highly disciplined body. It was one of his customs, also, when taking up a defensive position, to seck out a plateau, and establish himself behind the crest just in view of the enemy: The front slope was defended by shirmishers, who retired before the advancing French columns of attack, and revealed the real line of defence. The French employed small masses of battalion columns, each battalion covering its own front with a thick line of skirmishers. It was lield that the skirmishers, from the great freedom afforded them in taking advantage of cover, would advance with much less loss, and fire with greater effect, and that the column formation of the bodies in rear gave a solidity over the line that made their attack more formidable.

The introduction of arms of precision had, as may be imagined, its due effect on European warfare, and it was evident that the fighting tactics of Frederick the Great, which were improved by the Duke of Wellington to suit the arms of his day, were becoming obsolete. Jomini, recognising the importance of a good front of fire, and with the object of diminishing the losses which would be inflicted by the eneny's artillery, recommended, as the best mode of attack, battalion columns of three divisions each at deploying interval, the advance being preceded by skimishers. The French adopted this system in the Italian campaign of 1859 ; and the Prussians entered on the war of 1870-71 with the same idea that the attack, after an artillery preparation, was to be carried out by a line of skirmishers followed by closed columns of attack. It is unnecessary to give figures, illustrating the destructiveness of breech-loading fire delivered from behind cover, to prove the impossibility for infantry in columns or in line two-deep, each file occupying 24 inches of front, to march by daylight up to any position, no matter how brave that infantry might be.

Breech-loading rifles first came prominently into use in the campaign of 1866. They had previously been used by the Prussians in the Danish War, but the trifling events of that campaign were not sufficient to make their great superiority observable. 'The different actions of the campaign of 1860 may be said to have been gained mainly by infantry-not by the shock of columns, but by the fire of skirmishers; that is, those bodies of infantry that had hitherto followed the skirmishers in compact order now became dissolved during the action, and gradually pressed forward to fight in the skirmishing line. But it was not till the Franco-German War of 1870-71 that it was fully recognised that the rapidity of loading, with increased accuracy and range, would no longer permit infantry in masses to approach, as heretofore, positions defended by troops using breechloading rifles. The Germans, in the early part of the campaign, still endeavoured to approach defended positions in dense formations, covered by skirmishers; but the slaughter of the Prussian Guard at St. Privat was the culnuinating point. On that occasion the attack formation of each of

voL. XIIV. 
their two brigacles consisted of an entire battalion extended in front as skirmishers, followed by two lines of half-battalion columns in rear. The result showed that columns of attach were inadmissible under modern fire, and they were in consequence replaced by a line of men in extended order, incorrectly described as skirmishers, with supports and reserves also in extended order; so that the skirmishing line, from being originally the screen of the real attack, became itself the attacking party. The Russians, however, in the earlier actions of their war with the 'lurks, still formed their troops in two lines, with a reserve, the front being covered by a few skirmishers. The first line followed the skirmishers at about 150 to 200 paces, and the second line followed the first at about the same distance. The lines were formed either by battalions in company columns, or in solid line, and their skirmishing line was just strong enough to brush aside, as of old, any slight obstacles to the advance of the main body, which moved in more or less solid formations. In the later actions of the war, Skobeleff formed the rifle company of each battalion as the shooting line, in extended order, keeping one section in close order in rear to feed gaps. The other companies of the battalion followed at about 200 yards, formed in line, with intervals of two paces between files, one-fourth of each company being kept just behind to fill up losses in the ranks of the line. The second battaiion followed the first in the same' order at about 300 yards, while the third battalion remained in reserve. In this formation he captured the Green IHills, and carried the Turkish entrenchments at Shenovo. He subsequently gave it as his opinion that the only formation in which troops could in future successfully assault entrenched positions wàs in successive lines of extended men.

The specially instructed light infantry soldicr or rifleman seemed, therefore, to have lost his peculiar functions, since every infantry soldier was required to be, in one sense, a skirmisher. The "Soldiers' PocketJ3ook" silys:- "Skirmishers must learn to forget the old lessons they were taught as to their special functions in action." And as this represented the views of the military authorities, it is not surprising that on the appearance of the new Infantry Drill-Book, in 1892, the chapter dealing with skirmishing, Part VIII., was conspicuous by its absence. But with all deference, it may be submitted that an advance in a straight and rapid manner of a fighting line in single rank densely packed bears no resemblance whatever to shirmishing. It is not proposed here to suggest in what form a modern attack of a strongly defended position should be conducted. In all probability it would be found that a line of real skimishers, as they existed of old, would do no more than locate the enemy, and, as it were, brush away the cobwebs impeding the advanee of the main body. But it is submitted that there are other contingencies in which the services of properly trained skirmishers would be: cqually valuable-for instance, when smokeless powder conceals the position of an encmy, in localising him before an order of attack can be formed; on outpost duty, in searching for the enemy in his own ground when cavalry is not available; in reconnoitring, by keening constantly in contact with the enemy, and thereby obtaining accurate information of 
his movements and intentions; with the vanguard of an advanced guard, and in protecting the flinks of an advanced guard on the line of march in a hilly or mountainous country ; with rear guards, and in covering retreats ; in the defence of woods; in guarding convoys; and in hill fighting in India and elsewhere. In the latter connection the value of skirmishing has been fully appreciated in India. During the last frontier war the Gurkha scouts showed clearly what could be done with men properly trained as skirmishers and in scouting, provided they are good shots. It is not every man that can become a really good skirmisher or scout, any more than can every sportsman who carries a rifle in the highlands become a sood deer-stalker. Rapid movement, often prolonged steacly doubling, powers of observation, keen eyesight, an aptitude for taking cover, activity of mind and body, and good marksmanship, are necessary for a really efficient skirmisher.

In regard to ordinary European warfare, additional care in advancing appears to be now more than ever necessary, owing to the volume of fire which can be brought to bear from magazine rifles with smokeless powder. And it is in this direction that efficient shirmishing would be invaluable. All formed bodies require to have their front and flanks covered by infantry scouts, and a moving but very thin line of skirmishers, with their supports and reserves. This being the case, it would appear to be advisable to take in hand the instruction of the British soldier in skirmishing-an art in which he has, unfortunately, been permitted to lose his cunning.

For this purpose few better works exist than that published by the late Colonel G. Gawler, K.H., late 52nd Light Infantry, first produced in 1837 , with a second edition in 1852.1 He gives the eight essentials to good skirmishing as active intelligence, correct firing, daring courage, making the best of cover, presenting the smallest possible mark to the enemy's fire, maintaining extension from, and dependence on, a given file of direction, preserving a sufficient readiness to resist cavalry, and a judicious employment of supports and reserves. The true summit of perfection in skirmishing is: the preseration of order in disorder and of system in confusion; and for this purpose the skirmisher must be his own general and think for himself, and manouvre as if the fate of the day depended upon his conceptions. He must be a cool, steady, and accurate shot-one who never wastes a cartridge. He must be a man of daring courage, able to look after himself, and ready, if necessary, to fix his bayonet and dash to close quarters if the enemy, on tolerably equal terms, will stand for him. After courage and activity, his duty is to make the best of cover. There are too kinds of cover-bullet-proof cover and mere concealing cover. Ragged rocks, large trees, brick and stone walls and buildings, stout fences, and thick mud banks, constitute generally the first class; young plantations, gorse and underwood, hedges, slight fences, and narrow sand hills, the second. It is for the first that the eye of the good shirmisher continually seeks. The

There is a copy in the Library of the R.U.S. Institution, Miscellaneous Pamphlets, Vol. XXXIII. ; and the article was reproduced in the O.vfordshire Light Infantry Chronicle for 1897 . 
second, after fire completely opens, turned even to best advantage, is worth but little more than no cover at all; and is worse than no cover at all, if the men (which they are much disposed to do) collect in groups behind it. Skirmishers should offer as small a mark as possible, and should therefore move in single files from six to ten yards apart, except in thick, concealing cover, when-two or three may, without exposure, increase mutual confidence. But they should extend again directly good cover ceases. Extensions may be made from the right, left, or centre, but there must be a common centre of direction, connection, and extension, to avoid confusion, dispersion, or concentration. Infantry seem to unnecessarily fear cavalry; why, it is difficult to say. Skirmishers fear them even more. By the looseness of their formation they are, it is true, dangerously exposed to charges from small parties of an enemy's light cavalry; and in districts destitute of continuous fences, but aboundin hollows, isolated patches of wood, or other features convenient for concealment, such attacks may burst forth with confusing suddenness. But a point should be made of impressing upon skirmishers that, in these days, they have nothing to fear from cavalry. They may form small groups, and, standing shoulder to shoulder, avail themselves of hedges, trees, or any other obstacle at hand, and safely hold their own. Supports and reserves are absolute essentials to skirmishers. They are not only of great importance as rallying points in extraordinary cases of misfortune, but are the necessary aids to the ordinary movements of the extended line. Supports are useful for reinforcing and relieving the line of skirmishers, for prolonging its flanks or covering them, for strengthening them at any moment they find their numbers unequal to important work before them, for relieving them when they or their ammunition becomes exhausted, for coming up in close order to rush bridges, streets, villages, or other defiles too strongly occupied to be forced by the skirmishers, and to act against cavalry. Reserves supply the place of supports when necessary.

The general rules laid down in the now defunct Part VIII. of Infantry Drill were excellent. "Skirmishers are employed to reconnoitre the country in their front, feel for the enemy, or clear the way for troops advancing, and protect them from being too closely pressed either in flank, front, or rear, or harassed if obliged to retreat; they conceal the disposition and manouvres of their own troops, guard them against surprise, and watch the movements of the enemy. Wherever skirmishers are used they form a screen in front of the troops from which they have been pushed out; their action is covered from the rear, and their movements must be flexible in the highest degree. They will cover a wider or narrower front, diverge from the front or move directly to a flank, as circumstances may require; reinforcement or relief may become necessary, and they must be capable of resisting detachments of the encmy's cavalry. 'To attain these objects, it is essential that the soldier be trained to use his own powers of mind and body." But it is presumed that when skirmishers are extended the two men of a file, instead of standing and moving one behind the other, as in the Drill-Book, would 
be placed side by side, as in extending to single rank at the present day. The advantages of this are obvious. The supports and reserves should also be in extended order.

It is necessary that the duties of the skirmishing line be clearly defined. They are not a fighting line in extended order; they merely: fecl for the enemy, well ahead of the force covered by them. 'They may drive in small bodies, but in ordinary circumstances their province is not to attack but to hold in check till the main body has time to make its dispositions. The line of skirmishers may, and often should, be preceded by scouts, but this will not relieve the shirmishers of their individual duty of scouting. A line of direction should always be given and religiously maintained, and not until the enemy is encountered should any serious use be made of cover. 